\title{
IMPLEMENTASI NILAI-NILAI TA'LIM MUTA'ALLIM DALAM MENCEGAH MASUKNYA PAHAM RADIKALISME DI PONDOK PESANTREN
}

\author{
Oleh: \\ Ansari \& Edy Imam Supeno \\ Institut Agama Islam Ibrahimy Genteng Banyuwangi \\ ansaridosen1@gmail.com \& Iqoizzaayleennasywa@gmail.com
}

\begin{abstract}
:
Religion manipulator has become the enemy of us even tthre is no religion can tolerate violence in the name of religion. In fact, when someone wants to oppose a religion, a value of unity has existed, and it is difficult to avoid conflict. This study aims to realize the value contained in the ta'lim muta'allim so students or a boarding school environment is spared from radicalism. As a basic step, schools should be developed into modern boarding schools. First, it helps students understand the importance of values in human life. Second, direct students to always developing and deepening the value. Third, direct the students to be a good role model and responsible. So that boarding schools can increase the awareness of students through more in-depth research on the outside thinking of aqidah and fiqh, thus optimizing in the fight against radicalism and terrorism
\end{abstract}

Keywords: nilai ta'lim muta'allim, Radikalisme, Pondok Pesantren

\section{A. Pendahuluan}

Dalam kitab ta'lim muta'allim merupakan pegangan dan sekaligus pedoman bagi para santri dalam upaya memperoleh keberhasilan dalam menuntut ilmu, tentu ilmu yang bermanfaat lagi barokah yang dirasakan manfaatnya baik untuk nusa, bangsa dan agama. Namun akhir akhir ini justru banyak para penuntut ilmu yang mengalami disorientasi dari pada tujuan dan hikmah menutut ilmu itu sendiri, sehingga kita temukan banyak perilaku perilaku kontra produktif dilakukan oleh para pelajar, tawuran, pergaulan bebas, dan bahkan mereka terjangket dengan pahampaham radikalisme yang akan mengancam keutuhan Negara Republik Indonesia.

Akhir-akhir ini banyak pondok pesantren yang menjadi sorotan awak media, yang dikabarkan pondok pesantren terkesan menyimpang dari ajaran dan tradisi keilmuan dan pengembangan intelektual. Fokus 
aktivisme, misalnya Vildan Muhollad adalah teman atau pelaku bom bunuh diri di Suriah. Tingkah kejinya tak lepas dari komitmennya terhadap kelompok radikal Negara Islam (ISIS) di Irak dan Suriyah. Ia belajar Islam, Ramungan, dan Jawa Timur di sebuah pesantren, dan teroris seperti Imam Samudra percaya bahwa jihad adalah motivasi keagamaan untuk tindakan mereka. Ia mengatakan bahwa jihad atas nama agama merupakan bagian integral dari berjuang di jalan Allah SWT. ${ }^{1}$

Berjuang di jalan Allah SWT selalu diperankan oleh seorang pelaku bom bunuh diri yang tidak sengaja masuk pesantren dan akhirnya masuk pesantren, menjadi korban tudingan negatif dari berbagai kalangan masyarakat. Meski Islam sebagai agama rahmat, namun saat ini sedang dipersoalkan dan dituntut oleh masyarakat. Dalam riset menemukan Islam dapat melegitimasi kekerasan dan menekankan doktrin moralitas, etika, dan perilaku yang baik, mulia, dan berbudi luhur. ${ }^{2}$

Media Barat mengklaim bahwa pesantren telah menjadi "sarang" aktivisme dan terorisme. Dua hal yang berbeda, tetapi saling berhubungan, dan Azra menggambarkan serangan teroris di Indonesia sebagai terorisme impor daripada terorisme domestik, dan mengutip bukti polisi untuk menunjukkan bahwa para intelektual yang beraksi adalah Dr. Label radikalisme ini membuat al-Abu Bakar Baathir, kepala sekolah Pondok Pesantren Mukmin Nguqi Solo, bangga karena meyakini radikalisme berarti sikap tegas petani dalam menjalankan syariat Islam. ${ }^{3}$ Baathir Islam harus benar-benar mematuhi semua perilaku, tindakan dan pedoman yang melenceng dari al-qur'an. Dalam dekade terakhir, fenomena yang terjadi dikalangan pesantren maraknya aktivisme berbagai ormas Islam pasca runtuhnya orde baru, sikap moderat Pesantren seakan hilang. ${ }^{4}$

Penelitian ini menunjukkan bahwa pemahaman dan penerapan ajaran ideologi Aswaji berbeda dengan kelompok Islam lainnya seperti Muhammadiyah atau Nahdlatul Ulama (NU). Kedua organisasi ini digolongkan sebagai kelompok "Salafi Haraki" karena upaya mereka secara aktif mengupayakan pengembangan Manhaj Salafi. Meski keduanya tergolong "Salafi-haraki", namun tidak selalu sama dan konsisten dalam

1 Wildan, Muhammad, "Mewaspadai Bahaya Ekstremisme Dan Radikalisme Di Kampus," Lecturer at UIN Sunan Kalijaga Yogyakarta, 2018.

2 M Nuh. Nurison, Peran Pondok Pesantren Dalam Pembangunan Budaya Damai (Jakarta: Kementerian Riset dan Pengembangan Agama dan Biro Pendidikan, 2010), 1.

3 Ibid, 71.

4 Irfan Awwas Suryahardi, Dakwah \& Jihad Abu Bakar Ba'asyir (Yogyakarta: Wahdah Press, 2003), 30.

$360 \mid$ JURNAL LISAN AL-HAL 
pemilihan rujukan, kriteria Salafi, dan definisi panutannya. Karena perbedaan-perbedaan ini, kemudian dapat dikaitkan dengan sikap sempit ashabiyah (saleh). Dalam beberapa kasus, fanatisme ini dapat berkontribusi pada perkembangan radikalisme agama di Indonesia, khususnya di pesantren

Maka melalui pengamalan yang diharapkan mampu membentuk satu kepribadian yang utuh dari seorang pelajar/santri sehingga memiliki rasa dan keluhuran budi pekerti serta nilai kemanusiaan yang tinggi, relasi antara guru dan murid serta bagaimana kitab mutalim mengatur pola hubungan antar sesama pelajar, memilih teman yang baik, memilih topik bahasan atau keilmuan yang tepat serta yang paling penting adalah berguru kepada orang yang tepat.

Tentu para santri jika mampu mengamalkan betul dan mengimplementasikan nilai dalam kitab ta'lim muta'allim maka dinamika hari ini terjadi yang berkaitan dengan maraknya gerakan radikalisme dikalangan santri akan menemukan jalan keluarnya.

Berawal dari keunikan fenomena dan permasalahan, permasalahan tersebut baik (kenyataan yang tampak di lapangan) dan (seharusnya harapan atau cita-cita) yang ditemukan penulis di lapangan dan masih bersifat mendasar. Kebenaran yang komprehensif, objektif dan bertanggung jawab berguna untuk mengembangkan pesantren saat ini. Di sisi lain, jika kebenaran tidak diklarifikasi melalui penelitian ilmiah, prasangka yang tidak berdasar akan dikacaukan. Berdasarkan beberapa permasalahan di atas, perlu dilakukan langkah-langkah untuk memperkuat nilai "ta'lim muta'allim". Untuk alasan tersebut, penelitian ini dilakukan, untuk menciptakan, mencegah darai radikalisme.

\section{B. Metode Penelitian}

Metode penelitian ini mengadopsi penelitian standar; Dengan membaca dan menyunting bahan penelitian secara cermat pada topik yang dibahas untuk menemukan kebenaran konsistensi, penelitian ini menggunakan pendekatan konseptual. Selain itu, menggunakan metode kualitatif dengan teknik wawancara, observasi, serta pencatatan. ${ }^{5}$ Bahan penelitian menggunakan primer yang bereputasi, sedangkan bahan sekunder adalah publikasi dan pengumpulan. Pengumpulan data dengan cara mengkaji buku-buku kepustakaan dengan menggunakan sumber data dari literatur, baik berupa buku, jurnal, artikel, jurnal, maupun metode

5 J Lexy, Meleong, Metodologi Penelitian Kualikatif (Bandung: Remaja Rosada Karya, 2010), 5. 
analisis data dengan menggunakan metode deskriptif. Metode analisis dan metode analisis isi. ${ }^{6}$

\section{Hasil dan Pembahasan}

1. Nilai-Nilai Ta'lim Muta'allim

"Ta'lim Muta'allim" adalah karya klasik Syekh Burhanuddin AzZarnuzi, yang berisi tentang kode etik yang berlaku bagi siswa yang masih akan melanjutkan ke perguruan tinggi dan menjadi manusia dalam hal ilmu, kitab, guru dan ilmu praktis. Sebagai bagian dari persiapan kerja, Syekh Az-Zarnuji mengatakan: Setelah mengamati banyak pencari ilmu masa kini (anak-anak sekolah dan pelajar), ternyata banyak sekali ilmu yang mereka peroleh, namun tidak dapat menyadari manfaat dan hasilnya. abaikan syarat untuk mencari ilmu, Meskipun siapa pun yang melakukan kesalahan akan tersesat dan gagal mencapai tujuannya, tidak lebih, tidak kurang.

Dengan demikian, penulis ta'lim muta'allim mengupayakan agara kitab tersebut dapat dijadikan pedoman bagi santri khususnya santri yang ingin mendalami kitab tersebut. Penulis menuliskan agar santri dapat memanen hasil pengetahuan yang dibutuhkan. Firman Allah SWT, dalam al-qur'an yaitu:

"Orang-orang yang beriman, ketika seseorang berkata kepadamu: "Buatlah ruang dalam majelis" dan kemudian beri uang untuk anda, Allah akan memberi anda uang. Ketika dia berkata: Bangunlah, lalu bangunlah, Allah akan membuatnya di antara kamu orang-orang yang beriman dan orangorang yang dikaruniai ilmu akan bangkit secara bertahap, Allah mengetahui apa yang kamu kerjakan" 7 .

Karena tujuan paling utama dalam menuntut ilmu merupakan sebuah kewajiban atau keharusan untuk menjadi pribadi yang berakhlak mulia dan dermawan, Nabi ditus hanya untuk mengajar akhlak yang sempurna. Sabda Nabi SAW:

"Dia sudah memberitahu (Hannad bin Sarri) dari (Husain) dari (Salim bin Abu Al-Ja'di) dari (Jabir bin Abdillah) kepada kami ('Abtsar), dia berkata: Kami memiliki seorang putra, dia menamainya Muhammad. Maka kami berkata, Sampai kami mendapatkan persetujuan anda, kami tidak akan memberi anda nama panggilan dengan nama Rasulullah SAW. Kemudian orang iru datang kepada Nabi SAW berkata: Memang benar aku

\footnotetext{
${ }^{6}$ Sugiono, Metode Penelitian Kualitatif, Kuantitatif (Bandung: Alfabeta, 2009), 7. ART, 2004).

${ }^{7}$ RI Departemen, Agama, Al-Qur'an Dan Terjemahnya (Jakarta: CV. Jamanatul Ali-
}

$362 \mid$ JURNAL LISAN AL-HAL 
memiliki seorang anak laki-laki. Aku memanggilnya Muhammad, tetapi kaumku menolak untuk memanggilnya dengan nama itu untuk mendapatkan persetujuan dari nabi SAW. Dia berkata : Beri dia namaku, tepi jangan beri dia nama panggilanku. Karena aku diutus untuk membagi diriku diantara kalian sebagai qosim (Pemberontakan). Dalam menceritakan kepada kami (Rifa'an bin Al-Haitsam Al-Wasithi) dia juga memberitahu kami (Khalid) tentang Ath Thahhan dari (Husain) melalui atas ini, tetapi tidak menyebutkannya: Karena saya qasim (Pemberontakan) Dikirim untuk memecah belah anda." 8

\section{a. Kewajiban Belajar}

Rasulullah SAW bersabda: "Menuntut ilmu hukum merupakan kewajiban seseorang Islam peria dan wanita perlu diperhatikan sehingga keharusan seorang muslim untuk menuntut ilmu bukanlah untuk ilmu apapun, tetapi hanya untuk ilmu agama. Menjelaskan, bagaimana bergaul atau mencari ilmu lain (muamalah). Maka sebagian orang berkata: "Pengetahuan yang paling penting adalah pengetahuan yang benar tentang berbagai hal. Dan perilaku mulia merupakan menjaga perilaku dan tingkah laku kita.

"Ilmu tentang hal-hal yang memahami ilmu agama Islam yang dibutuhkan saat itu, seperti shalat. Karena setiap muslim memiliki kewajiban untuk mengetahui ilmu yang berkaitan dengan shalat, sebagai rukun dan syarat efektifnya shalat, dapatkah ia shalat dengan sempurna. Dengan demikian mempelajari ilmu yang berkaitan dengan kewajiban yang akan dia lakukan. Karena benda merupakan perantara untuk melaksanakan kewajibannya, maka perantara penelitian merupakan syarat wajib secara hukum. Ilmu agama adalah bagian dari pemenuhan kewajiban agama Vasilla. Contohnya ilmu puasa, zakat orang kaya, haji terjangkau, dan ilmu jual beli" ${ }^{9}$.

\section{b. Pentingnya Niat Ketika Belajar}

Undang-undang mengamanatkan agar peserta didik memiliki niat sebelum mulai belajar dan mencari ilmu, karena niat tidak dapat dipisahkan, karena niat sangat besar pengaruhnya terhadap hasil belajar. Seperti yang dikatakan Nabi Muhammad SAW:

"Dia memberi tahu kami (Yahya bin Qaza`ah) dia memberi tahu

8 Muslim, 3977.

9 AZ Zarnuji, Ta'lim Muta'allim Thariq At-Ta'allum (Bairut Lebanon: Dar AlKottob Al-ilmiyah, 2012), 80. 
kami (Malik) (Yahya bin Sa id) dari (Muhammad bin Ibrahim bin Al Harits) dari (Alqamah bin Waqash) berasal dari (Umar bin Al Khaththab) radliallahu'anhu berkata; Nabi Shallallahu alaihi wasallam bersabda: "Sesungguhnya setiap perbuatan tergantung niatnya. Bagi seseorang, ini adalah niatnya.

Orang yang belajar dan mencari ilmu untuk menghilangkan kebodohannya adalah netan yang baik dan aktif, sehingga dapat memberikan manfaat bagi lingkungan dan masyarakat, oleh karena itu ia harus sungguh-sungguh mencari ilmu agar ilmu yang diperoleh bermanfaat. Niat sangat berpengaruh, dan niat yang diperbolehkan hanyalah niat baik. Jangan mencoba mencari pengaruh agar orang-orang di sekitar Anda berpaling kepadanya, mencari status di mata penguasa dan orang lain.

\section{c. Kesungguhan Belajar}

Belajar untuk ikhlas, dan belajarlah dengan tekun. Hali ini sudah tersirat dal a-qur'an sesuai firman Allah SWT:

"Dan mereka yang memperjuangkan kita (kebahagiaan) pasti akan kita tunjukkan jalan kita. Sesungguhnya Allah bersama orang-orang yang berbuat baik" 10 .

Wahyu: "Siapa pun yang dengan tulus mencari akan menemukannya" 11. Begitu banyak usaha yang akan diperoleh seseorang. Pencarian ilmu membutuhkan ketekunan dan keteguhan batin, belajar salah satu dari tiga unsur, santri, guru, dan orang tua jika masih hidup.

Syekh Imam Al Ajal, Sadiduddin membacakan untuk saya sebuah puisi yang ditulis oleh imam Syafi'i 12 .

"Ketekunan menutup jarak, dan ketekunan juga bisa membuka pintu yang tertutup"

"Makhluk Allah SWT, yang patut dipermalukan dan diperhatikan adalah orang-orang dengan cita-cita luhur, tetapi mereka telah menjalani ujian berat dalam hidup (berpikiran sempit)"

"(Kecuali kadha' dan takdir Allah SWT), karena beberapa kontroversi menunjukkan bahwa kadha' dan hukum Allah SWT. Dia adalah orang yang cerdas (rasional) dan hidupnya sulit, dan bodoh orang menikmati kesenangan hidup )hidup itu indah)"

"Namun, orang yang memperoleh penghidupan yang kaya (pintar) tidak

10 Departemen, Agama, Al-Qur'an Dan Terjemahnya.

11 Zarnuji, Ta'lim Muta'allim Thariq At-Ta'allum, 37.

12 Ibid, 37.

$364 \mid$ JURNAL LISAN AL-HAL 
dapat kaya (hidup dalam kemiskinan). Padahal, keduanya selalu berlawanan arah, antara utara dan selatan.

\section{b. Sabar dan Tabah dalam Belajar}

Mengetahui bahwa kesabaran dan ketekunan adalah dasar dari kebajikan sehingga dapat melakukannya. Sebagaimana ayat tersebut mengatakan: "Segala sesuatu memiliki tujuan yang tinggi, tetapi jarang orang yang memiliki hati yang teguh ${ }^{13}$."

Mengatakan, "Kebenaran adlah kesabaran sesaat" oleh karena itu, yang terbaik bai siswa adalah memiliki hati yang teguh. Pelajarilah, dari guru dengan sabar. Pesan, jangan tinggalkan sampai anda benar-benar mempelajarinya. Dalam satu bidang ilmu, jangan pindah ke bidang lain sampai anda sudah memahaminya. Kecuali terpaksa, tidak boleh pindah ke tempat lain. Melanggar hal ini dapat menimbulkan kekacauan, keresahan, pemborosan waktu, dan menyakiti hati guru.

Menganjurkan agar para siswa selalu menjaga kesabaran mereka untuk mengendalikan keinginan mereka. Seorang pujangga berkata: "Emosi itu hina, siapa yang bernafsu akan mengalahkan orang yang rendah hati".

Kita harus memiliki kesabaran dalam menghadapi cobaan dan bencana. Dikatalkan: "Sumber kebahagiaan dapat ditemukan dalam banyak cobaan." Munurut saya, sebagian orang mengira bahwa puisi ini ditulis oleh Sayyidina Ali bin Abi Thalib r.a, isinya adalah sebagai berikut: "Kumu tidak dapat memperoleh pengetahuan tam [pa menggunakan 6 senjata. Saya katakan, semuanya jelas. 1). Cerdas 2). Kedermawanan 3). Sabar 4). Tentatif 5). Diinstruksikan oleh guru 6). Panjang.

\section{c. Memilih Teman}

Dalam memilih teman, sebaiknya pilihlah yang rajin, baik hati, jujur, dan mudah dimengerti. Hindari kemalasan, pengangguran, penipuan, sabotase, dan fitnah ${ }^{14}$. Puisi itu berbunyi:

"Jangan tanya siapa dia, tapi lihat siapa temannya. Karena siapa pun dia, dia harus seperti temannya. Ketika temannya memberontak, segera hindari dia. Jika dia baik dan memeluknya, Anda akan bahagia. "

Disyirkan untukku: "Jangan menemani kemalasan, hindari semuanya. Banyak orang saleh terjebak oleh kerusuhan. Kebodohan menyebar ke para sarjana dengan cepat seperti bara api.

\footnotetext{
13 Ibid, 37.
}

14 Ibid, 39. 
Nabi SAW bersabda: "Semua bayi dilahirkan dalam keadaan suci Islam, sampai kedua orang tuanya membiarkan mereka menjadi orang Yahudi, Kristen atau penyihir. "Sebuah kata bijak yang berbahasa Persia: "kawan memberontak sangat beracun dari ular yang berbahaya." Allah SWT berfirman bahwa teman yang buruk dapat membawa anda dalam api neraka, sedangkan kawan baik akan membawa kita ke surga.

Narasi: "Jika Anda ingin mendapatkan ilmu bermanfaat, Anda harus mengetahui segala sesuatu tidak berwujud kemudian dapat mempromosikannya, sehingga dapat mepelajari isinya dan bersamanya darinya."

Disisi lain, menurut Sirry, fundamentalisme dan radikalisme adalah istilah yang biasa digunakan untuk menyebut revivalisme di luar tradisi yang dianut ${ }^{15}$. Istilah ini memiliki semboyan politik untuk membenarkan pembicaraan sepanjang waktu oleh kelompok-kelompok gerakan keagamaan. Menurut Bruce, dalam tradisi agama mana pun orang dapat menemukan dua sekte yang kontradiktif: ekstrem konservatif dan tradisionalis, moderat dan radikal ${ }^{16}$.

Dalam posisi lain, Gus Dur, mengatakan bahwa klaim-klaim radikalisme Agama menurut Al-Qur'an dan Hadits, tetapi sebenarnya merupakan hasil usaha manusia ditambah dengan kedudukan, waktu, dan kemampuan pelaku yang memperhatikan kemungkinan keuntungan dari seseorang Jangan mengesampingkan ${ }^{17}$. individu atau kelompok. Dengan demikian, menurut Gusdur, gerakan Islam radikal tidak terlepas dari berbagai kepentingannya, dan tidak ada gerakan keagamaan yang murni.

Kitab Ta 'lim muta`allim karya Syekh al-Zarnuji memuat etika yang harus dipatuhi oleh para santri. Oleh karena itu, pembahasan dalam buku ini sangat relevan dengan upaya pencegahan invasi radikal terhadap pesantren, salah satunya yang harus dimiliki santri yaitu realisasi dan implementasi, merupakan nilai kepribadian yang patut diperhatikan.

Kepribadian adalah sifat dan kepribadian orang yang berbuat baik, yang membedakan orang. Seseorang dengan kepribadian memiliki kepribadian dan kepribadian. Erich Fromm 18, filosof besar tahun,

15 A Sirry, Mun'in, Membendung Militansi Agama: Iman Dan Politik Dalam Masyarakat Modern (Jakarta: Erlangga, 2003), 3.

16 Bruce Steve, Fundamentalisme: Pertautan Keberagaman Dan Modernitas (Jakarta: Erlangga, 2000), 130.

${ }^{17}$ Abdurrahman Wahid, Ilusi Negara Islam: Ekspansi Gerakan Islam Transnasional Di Indonesia (Jakarta: The Wahid Institute, 2009), 18-19.

18 Yamin Moh, Menggugat Pendidikan Indonesia (Yogyakarta: Ar-Ruz Media, Cet. 1, 2009), 22.

$366 \mid$ JURNAL LISAN AL-HAL 
mengemukakan bahwa alasan dan motivasi seseorang yang sadar atau tidak sadar untuk melakukan suatu tindakan tertentu (behavioral trait) pada suatu sifat kepribadian (personal trait). Erick From mengatakan bahwa hakikat alam terdapat dalam lingkungan, dan objek (asimilasi) terdapat dalam pola hubungan dengan manusia (sosialisasi). Istilah kepribadian bagi sebagian orang dikatakan sama dengan kepribadian. Kepribadian itu sendiri adalah "sifat, sifat, gaya, dan sifat seseorang yang diterima melalui lingkungan".

Ini adalah perwujudan dari setiap barang bergerak yang ada dan dua nilainya ${ }^{19}$. Nilai-nilai adalah keyakinan atau keyakinan yang mendasari orang untuk memilih tindakan mereka dan untuk mengevaluasi sesuatu yang berarti dalam hidup.

Menurut Webster ${ }^{20}$, "nilai adalah spin-off, dan tampaknya diinginkan untuk memiliki nilai kualitas standar." Nilai adalah keyakinan seseorang bahwa mereka selalu percaya pada hal-hal duniawi, dan nilai merupakan dasar untuk memilih tindakan apa yang akan dilakukan individu atau kelompok, atau untuk menilai apa yang berarti atau tidak berarti dalam kehidupan seseorang.

Nilai adalah konsep manusia yang abstrak, baik dianggap perbuatan baik, baik, jahat, maupun jahat. Nilai-nilai mengarah pada tindakan dan kepuasan sehari-hari.

\section{d. Manipulator Agama}

Radikalisme berasal dari akar kata latin yaitu akar pemikiran yang mendalam untuk mencapai suatu tujuan yang diinginkan. Kaum radikal mengungkapkan, apakah mereka percaya pada keyakinan bahwa harus ada perubahan sosial atau politik yang besar atau ekstrem. Radikalisme menuntut perubahan dengan sepenuhnya mengubah pengertian tentang kondisi kehidupan masyarakat dan menggantikan sistem kehidupan sosial. Saya pikir radikal adalah hal yang paling ideal untuk mengubah sistem perencanaan yang digunakan. Dalam konteks radikalisme ini, seringkali didasarkan pada pemahaman agama yang sempit, yang berujung pada teror bom yang tumbuh bersama sistem. Sikap ekstrem ekstrem berlipat ganda di tengah Panggung Agung dengan tujuan menunjukkan kemiskinan, ketimpangan sosial, atau ketidakadilan ${ }^{21}$.

19 Muhaimin, Pendidikan Islam: Mengurangi Benang Kusut Dunia Pendidikan (Jakarta: PT. Raja Grafindo Persada, 2006), 148.

20 Ibid, 148.

21 Zuly Qodir, Radikalisme Agama Di Indonesia (Yogyakarta: Pustaka Pelajar, 2014), 117. 
Definisi radikalisme masih diperdebatkan implikasinya terhadap tindakan terorisme. Istilah radikalisme dicetuskan oleh Presiden Joko Widodo (Joko Wi) untuk belakangan ini berganti nama menjadi manipulator agama. Joko Widodo, mengutip pernyataannya sendiri, pernah berbicara tentang penggunaan istilah baru untuk menggantikan kata radikal. "Saya tidak tahu. Apakah ada istilah lain yang bisa saya gunakan, seperti manipulasi agama? ${ }^{22}$.

Radikalisme memiliki beberapa langkah dan jalan yang membuat seseorang tiba-tiba terjerumus ke dalam radikalisme dari pada percaya. Langkah-langkah seseorang menjadi radikal, dikutip dari New York Police Department 23, merinci proses seseorang menjadi aktor radikal. Konfigurasi panggung:

Tabel 1.1 Tahapan Seseorang Menjadi Radikal.

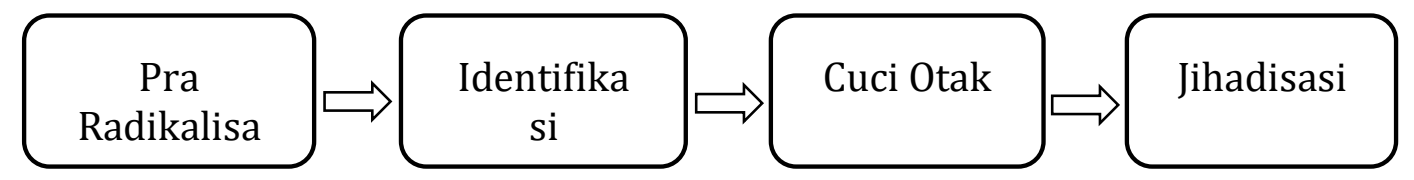

1. Pra-radikalisasi Tahap pertama ini dimulai ketika seseorang menjalani kehidupan sehari-hari sebelum terpapar radikalisme.

2. Identifikasi otomatis, tahap ini dimulai ketika seseorang mempersepsikan dirinya sebagai ideologi radikal dan mulai mengidentifikasi. Seseorang mulai mengubah keyakinannya dan perlahan mulai bergaul dengan orang lain yang memiliki ideologi yang sama. Salah satu contohnya adalah menemukan identitas keagamaan.

3. Cuci otak langkah ini terlihat dari keyakinan dan keyakinan seseorang terhadap idealisme yang dianut. Pada tahap ini, tanpa mengejar kebenaran dan keabsahan pemahaman tersebut, ia dapat berasumsi bahwa idealisme yang ia anut adalah benar.

4. Jihadisasi; Tahap akhir dimana seseorang mulai bertindak sesuai dengan apa yang dia yakini. Pada tahap ini, tindakan individu dapat melakukan berbagai tindakan kekerasan yang dilatarbelakangi oleh inisiatif individu dan organisasi yang diterima, dan bentuk

22 Tempo, "Jokowi Usul Ganti Istilah Radikalisme Jadi Manipulator-Agamal," Nasional.Tempo.Co, 2019.

23 SB Agus, Darurat Terorisme Kebijakan Pencegahan, Perlndungan Dan Deradikalisasi (Jakarta: Daulat Press, 2014), 156-157.

$368 \mid$ JURNAL LISAN AL-HAL 
tindakannya adalah penafsiran agama yang sempit, vandalisme, kekerasan komunal dan residivisme.

Radikalisme dapat dibagi menjadi dua bentuk: pemikiran dan tindakan. Sebagai bentuk pemikiran, radikalisme berfungsi sebagai ide abstrak dan membahas serta mendukung cara (kekerasan, dll) untuk mencapai tujuan tersebut. Sebagai bentuk aksi, radikalisme biasanya sudah termasuk dalam jaringan teroris, dan melakukan tindakan kekerasan dan kekacauan untuk mencapai tujuannya di bidang agama, sosial, politik dan ekonomi. Pada tahap ini, radikalisme mulai bersinggungan dan memiliki unsur terorisme yang memungkinkan para pelaku potensial untuk berkembang dan menangani terorisme ${ }^{24}$.

Secara sederhana, radikalisme adalah, dan dicirikan oleh, suatu gagasan atau sikap. Jadi ada 4 katagori yaitu: 1). Menunjukkan sikap toleran tanpa terlebih dahulu menghargai pendapat atau keyakinan orang lain. 2). Fanatisme, yaitu perasaan bahwa pendapat seseorang itu benar dan pendapat orang itu salah. 3). Sikap eksklusif yang membedakan diri dengan kebiasaan orang lain. 4). Sikap revolusioner cenderung menggunakan kekerasan untuk menyelesaikan masalah guna mencapai keinginan dan tujuan 25 .

Tidak ada perintah jihad menggunakan kekerasan dalam Al-Qur'an dan Hadits. Islam adalah agama yang menjunjung tinggi perdamaian dan kepedulian. Pada paragraf di atas, istilah radikalisme dikatakan telah dicetuskan di Eropa Barat, namun ada jejak sejarah radikalisme di kalangan umat Islam.

Sejarah perilaku kekerasan Islam umumnya muncul karena masalah politik dan mempengaruhi agama sebagai simbol umat manusia. Ini adalah fakta sejarah yang tidak salah lagi dalam teori yang ada. Pembunuhan khalifah merupakan awal dari munculnya radikalisme Islam. Namun, sementara gerakan radikal itu sistematis dan sistematis dalam menyebabkan pemberontakan di bawah kekuasaan Islam, awal gerakan radikal baru terjadi setelah Khalifah Alibin Abi Tholib memerintah Perang Sippin. Pemberontakan ini disebabkan oleh munculnya gerakan teologi radikal yang disebut kelompok Khawarij. Tidak hanya itu, ketika Ali masi berkuasa di Khalifah, Khawarij memperjuangkan kelanjutan kekuasaan Islam antara dinasti Umayyah dan Abbasiyah. Oleh karena itu, mereka

\footnotetext{
24 Ibid, 155.

25 Agil Asshofie, “Radikalisme Gerakan Islam,” Agilasshofie.Blogspot.Com, 2011,. \begin{tabular}{l|l} 
JURNAL LISAN AL-HAL & 369
\end{tabular}
} 
memilih Imam sendiri dan terus berjuang melawan kekuasaan Islam untuk mendirikan sistem pemerintahan Khawarij 26.

Islam tidak menoleransi tindakan kekerasan, dan tidak memperluas kepentingan agama, agama dan politik. Namun, tidak dapat disangkal bahwa dalam sejarah, kekerasan telah digunakan untuk mencapai tujuan politik, mempertahankan kepentingan agama yang ketat dalam kata-kata peradaban global, dan ada beberapa kelompok Islam. Ini sering disebut sebagai ekstremisme Islam ${ }^{27}$.

Adinal yang dibawa oleh Nabi Muhammad adalah agama yang mengajarkan perdamaian dan keamanan di dunia Islam dan di kehidupan akhirat. Secara harfiah, Islam berarti berserah diri kepada Tuhan dan kedamaian. Kedamaian Islam mengacu pada keadaan batin yang ada pada individu yang mengamalkan Islam, yaitu mereka yang ingin memahami dan mengamalkan kehendak Allah. Namun perjalanan hidup tidak terlepas dari masalah yang kita hadapi saat ini. Hal ini mempengaruhi pemahaman dan pengamalan agama. Karena mencakup keyakinan dan nilai-nilai, kadang-kadang berlarut-larut ke ekstrem.

Menurut Yusuf al-Karudawi 28, faktor utama munculnya radikalisme dalam agama adalah kurangnya pemahaman yang benarbenar mendalam tentang hakikat ajaran Islam itu sendiri dan kurangnya pemahaman teks-teks agama secara literal. Seseorang yang bingung tentang kehidupan mudah untuk menembus pemahaman teks yang akan mengarah pada pemahaman yang mendasar. Pemahaman mendasar yang mengarah pada aksi terorisme adalah sikap umat Islam untuk tidak mendalami dasar agama. Al-Qur'an telah menurunkan ajarannya melalui rukun iman dan rukun Islam. Mereka yang menggunakan kekerasan untuk mencapai tujuannya secara radikal benar-benar berasal dari landasan agama, yaitu rukun Islam dan rukun iman.

\section{Pondok Pesantren}

Pesantren memiliki banyak variasi dalam pengertiannya. Secara etimologi, pesantren adalah pondok. Sedangkan kata pondok bermula dari bahasa arab yaitu funduk (hotel) kemudian di Indonesia libih dikenal

26 Nasution Harun, Islam Rasional: Gagasan Dan Pemikiran Prof. Dr. Harun Nasution (Bandung: Mizan, 1996), 124.

27 Emmanuel Karagiannis, "Political Islam in Uzbekistan: Hizb Ut-Tahrir alIslami," Europe-Asia Studies 58, no. 2 (2006): 261-280.

28 John L Esposito and Syafruddin Hasani, "Unholy War: Teror Atas Nama Islam. Terj," Syafrudin Hasani, Yogyakarta: Ikon Teralitera (2003), 30.

$370 \mid$ JURNAL LISAN AL-HAL 
dengan kata padepokan yang dirancang berupa kamar-kamar sebagai asrama. Adapun pesantren adalah gabungan dari kata pe-santri-an berarti tempat tinggal santri ${ }^{29}$.

Imam Zarkashi dengan jelas mendefinisikan pesantren merupakan lemabaga sebagai tempat belajar santri untuk menimba pengetahuan 30 . Pesantren merupakan lembaga agama yang di dalamnya termuat pendidikan, pengabdian dan penelitian yang memprioritaskan fokusnya pada pendalaman pengetahuan baik Islam maupun ilmu lainnya. Sejak pesantren menjadi lembaga pendidikan, tidak punya tempat untuk santri. Oleh karena itu, petani saat ini telah menjadi suatu sistem dengan berbagai elemen yang saling berhubungan dengan pendidikan. Pesantren adalah lembaga dengan sumber daya pendidikan untuk mencapai tujuan individu dan institusional. Untuk mencapai tujuan kami, sistem dan perangkat selalu terhubung ke elemen yang saling terkait 31 .

Oleh karena itu penulis dapat menyimpulkan pesantren merupakan asrama bagi satri yang menimba ilmu dari para pengajar (Kiyai, ust/ustzah). Pertama, Nasir Ridawan, menyebutkan pesantren merupakan lembga agama untuk menyelenggarakan pembelajaran pendidikan untuk pengembangan atau penyebaran pengetahuan ${ }^{32}$. Kedua, Norcholis Madjid, pesantren merupakan produk peradaban Indonesia, dibangun sebagai lembaga atau lembaga pendidikan keagamaan dengan pola adat (asli) tradisional dan khas ${ }^{33}$. Ketiga, Dhofir Zamakhasari, pesantren merupakan tempat tingga mapun asrama bagi santri ${ }^{34}$.

Menurut Taqiyuding yang menjadi tujuan didirikannya pesantren, Kementerian Pendidikan Agama telah mencanangkan standardisasi pendidikan pesantren dengan tujuan agar pesantren dapat memberikan pendidikan kepada santri:

a. Memperoleh ilmu agama (tafaquh fiddin) dan melahirkan manusia yang mutafaqqihfiddin.

${ }^{29}$ M Ridlwan Nasir, Mencari Tipologi Format Pendidikan Ideal: Pondok Pesantren Di Tengah Arus Perubahan (Pustaka pelajar, 2005), 80.

${ }^{30}$ Amir Hamzah Wiryosukarto and Ahmad Fuad Efendi, "KH Imam Zarkasyi Dari Gontor Merintis Pesantren Modern” (Ponorogo: Gontor Press, 1996), 5.

31 Zamakhsyari Dhofier, "Tradisi Pesantren, Cet," VI, Jakarta: LP3ES (1994), 45.

${ }^{32}$ Nasir, Mencari Tipologi Format Pendidikan Ideal: Pondok Pesantren Di Tengah Arus Perubahan, 81.

33 Nurcholis Madjid, Bilik-Bilik Pesantren: Sebuah Potret Perjalanan (Paramadina, 1997),

34 Dhofier, “Tradisi Pesantren, Cet”, 46. 
b. Ikuras semata-mata pengabdian dan pengabdian kepada Allah dan tekun dalam memahami mata pelajaran yang diajarkan.

c. Untuk menghayati Sunnah Nabi dan menyebarkan ajaran ajarannya sepenuhnya (Kaffah).

d. Berkepribadian baik, berpikir kritis, berjiwa dinamis dan istiqomah.

Berwawasan luas, bijaksana, taat terhadap aturan, memiliki kepribadian yang baik dan dapat diandalkan.

\section{Motivasi tentang Model Pembelajaran Santri di Sekolah Boarding Islam}

Setiap pesantren mempunyai profil dan model pembelajaran sesuai dengan keburtuhan dan tujuan pendidikan untuk mencapai tujuan pesantren. Sampel pembelajaran yang dominan yang diterapkan di pesantren adalah model demokrasi untuk aspek pengajaran. ${ }^{35}$ Untuk santri di pesantren tidak terinfeksi virus politik agama, menjadi terorisme, pengasuh yang telah menerapkan aturan dan mencegah paham, pemikiran radikal dengan cara:

a. Perkuat pembelajaran

b. Pengakuan sebelumnya tentang mental santri. Tanggungjawab pengasuh untuk mendidik dan memberikan nasehat agara mental santri tidak merasa dikucilkan

c. Implementasi aturan untuk santri setelah disosialisasikan terhadap wali santri maupun orang tua kemudian aturan tersebut diterapkan untuk dijalankan

d. Disiplin

e. Menawarkan berbagai fasilitas dan keterampilan olahraga.

f. Kuliah Agama. Pesantren sejauh mungkin memberikan kiat untuk memotivasi Santri. Kuliah dapat dilakukan dengan model sekolah boarding secara umum. Selain itu, kegiatan pesantren diselenggarakan dengan memberikan peluang dialog langsung dengan aset mereka pada topik-topik Islam yang meminta pemikiran semua santri.

g. Dilarang dengan menggunakan HP Telephone (HP). Untuk tujuan agar tidak merusak fokus pembelajaran, dan tidak menimbulkan dampak negatif pada kelompok-kelompok menyeluruh.

h. Santri harus hidup di asrama (kos).

35 Mohammad Faqih Nursyamsu Mt, "Dinamika Sistem Pendidikan Di Pondok Pesantren Dalam Mengahadapi Era Globalisasi: Studi Multikasus Pondok Pesantren Darul Huda Mayak Ponorogo Dan Pondok Pesantren Thoriqul Huda Cekok Ponorogo" (Universitas Islam Negeri Maulana Malik Ibrahim, 2016), 26.

$372 \mid$ JURNAL LISAN AL-HAL 
i. Keberadaan Santri di luar pesantren sulit dikendalikan dengan pendidik yang tidak dapat berpartisipasi dalam semua kegiatan santri. Untuk alasan ini, pengasuh mengharuskan santri tinggal di asarama pesantren yang sudah disediakan, agar pengasuh dengan mudah mengendalikan kegiatan santri setiap hari.

\section{Faktor-Faktor Mendukung dan Menghambat Sampel Pembelajaran Santri di Asrama}

a. Faktor-faktor mendukung

Faktor dukungan untuk model pembelajaran dalam prediksi internat Islam radikalisme ${ }^{36}$, yaitu:

1) Aturan ketat. Ketentuan yang diterapkan oleh pesantren adalah hukuman, dan pendampingan yang sangat ketat.

2) Bahan Tauhid, program moralitas dan pengajaran ibadah masih dipertahankan sebagai pembeljaran yang diajarkan pda santri.

3) Paket memperbaiki aktivitas santri. Kepadatan jadwal santri membuatnya rajin dan disiplin dan sesuai dengan pedoman dan pengasuh

4) Masih tinggi sikap santri untuk guru/ust dan pengawas yang diidentifikasi sebagai hubungan anak dengan orang tua mereka. Asupan pengasuh baik untuk memposisikan orang tua mereka setiap saat untuk memperingatkan anak-anak mereka. Kehormatan santri akan menghasilkan sikap penuh, dengan ketaatan.

5) WORRAGE dalam pendidikan utama yaitu ibadah dan moralitas. Kenakalan santri bukanlah halangan bagi pengasuh dengan semangat nutrisi Akidah, ibadah dan moralitas dalam membina.

6) Masih banyak pola yang diungkapkan oleh pengasuh untuk santri. Guru/ust adalah contoh bagi para santri untuk selalu tekan mencari ilmu. Jika Anda selalu memberikan contoh yang baik dari sebuah contoh, Santripun akan selalu memiliki moralitas yang baik.

7) Hiburan dalam rangka mencegah stres dengan tujuan menghilangkan pengat terhadap santri seperti museum dan hiburan untuk menghilangkan pemikiran negatif.

b. Faktor menghambat

Selain faktor pendukung, ada juga hambatan yang kadang-kadang merupakan hambatan untuk pelaksanaan model pembelajaran di

36 Rakhmawati Rakhmawati, "POLA PENGASUHAN SANTRI DI PONDOK PESANTREN DALAM MENGANTISIPASI RADIKALISME: Studi Pada Pesantren Ummul Mukminin Dam Pondok Madinah," Jurnal Diskursus Islam 1, no. 1 (n.d.): 36-55. 
pesantren yaitu:

1) Faktor paksa dari orang tua. Masih ada orang tua yang memaksakan anak-anak mereka di pesantren untuk membuat anak-anak tidak termotivasi, pelajaran, pesimisme, tidak ada disiplin, ketidaksabaran kemudian menciptakan kenakalan santri.

2) Intervensi orang tua berdasarkan sekolah dan asrama. Intervensi orang tua terlihat ketika putra dihukum karena pelanggarannya karena dia melakukannya karena anak itu tidak menerima hukuman, yang dikeluhkan oleh santri kepada orang tuanya. Tidak aneh ketika orang tua bereaksi terhadap penulisan protes, atau orang tua datang langsung ke pengasuh yang telah menghukum anak-anak mereka di pesantren.

3) Staf yang meningkat untuk pengawas tidak optimal. Peningkatan pengawas SDM memengaruhi santri-nya yang sangat dipengaruhi. Selain hubungan akademik dari S1 ke S2 dan S3, ada banyak jenis pengetahuan tentang model pembelajaran santri. Juga menghasilkan kerja sama yang baik antara pengasuh.

4) Pembelajaran harus menjadi beban dan berbagi tanggungjawab semua administrator pesantren. Kebutuhan untuk memahami model pembelajaran juga penting bahwa santri tidak bisa bingung jika Anda memiliki model lain di bawah pengasuh.

\section{Mencegah Masuknya Paham Radikalisme di Pesantren}

Menurut penulis, langkah yang paling utama untuk mencegah paham atau pemikiran yang radikal yaitu:

a. Sosialisasi pemahaman agama yang moderat dipandang sama pentingnya sebagai upaya melawan budaya kekerasan di kalangan pelajar. Pengasuh, apapun pelajarannya dapat menyampaikan pesanpesan yang bermakna untuk meningkatkan pemahaman santri.

b. Membantu santri memahami nilai-nilai perdamaian, persaudaraan dan kasih sayang. Juga memahami pentingnya pelatihan hukum, mengadvokasi keadilan, menoleransi setiap perbedaan yang mungkin timbul perbedaan.

c. Periksalah buku yang ada di perpustakaan sehingga dapat dibaca kemudian dianalisa.

Santri dapat membaca dan membuka kitab-kitab yang ada di perpustakan sekolah maupun pesantren ${ }^{37}$ :

37 Nahidi Ahmad, Nuhu, Buro Fur Islamische Internate Und Sozialen Wandel (Jakarta: Pusat Pengembagan, Penelitian dan Keagamaan, Kementerian Agama, Republik Indonesia, n.d.).

$374 \mid$ JURNAL LISAN AL-HAL 
a. Memperbaiki arti jihad, agar tidak disalah artikan oleh para santri.

b. Kesalahpahaman tentang makna jihad menyebabkan radikalisme agama dan akhirnya terorisme, seperti yang dilakukan Amrozi dan lainlain.

c. Deteksi dini gangguan jiwa siswa ditujukan untuk memperhatikan siswa yang berpotensi mengalami radikalisasi. Gejala pertama yang terlihat jelas pada sikap mental dan kepribadian siswa yang kaku. Deteksi dini dapat meminimalkan penyebarannya ke siswa lain dan dapat membangunkan siswa sebelum mereka menjadi bingung.

d. Menetapkan kemandirian bagi Santri dengan premis bahwa setelah mereka meninggalkan Pesantren, mereka tidak akan mengalami kesulitan keuangan. Selain pengetahuan agama sebagai modal hidup, keterampilan kewirausahaan yang diperoleh di pesantren juga memungkinkan mereka untuk memiliki kehidupan yang mandiri.

e. Dengan menjalin kerja sama untuk mendorong santri memahami bagaimana mencegah gejala radikalisme. Melalui kegiatan misal perkemahan santri, pekan olahraga santri, manajemen jaringan dan media yang komprehensif.

f. Membuka ruang dialog bagi mahasiswa, sehingga mahasiswa dapat melihat sesuatu secara kritis, untuk menentukan pemahaman santri saat mempelajari mata pelajaran tersebut 38 .

g. Menciptakan peran serta Alumni, sudah menjadi keharusan pengasuh memfasilitasi terbentuknya Ikatan Alumni dalam hal in salah satunya untuk mendukung kegiatan yang dilakukan oleh organisasi ikatan alumni. Dengan dibentuknya organisasi alumni, para pendidik juga dapat mencari dan membimbing anak-anak sekolah, meskipun alumni, karena para pembunuh biasanya melakukan tindakan mereka setelah meninggalkan Pesantren dan merasa tidak ada hubungannya dengan itu. Bahkan, akibat perbuatannya itu akan mencoreng reputasinya di pesantren yang ia hadiri.

h. Untuk menciptakan model pendidikan yang efektif dan memprediksi radikalisme di kalangan siswa, pengasuh harus memiliki perspektif Islam yang luas. Meskipun kurikulum tertulis mengecualikan radikalisme, pendidik memainkan peran yang sangat penting dalam mempromosikan nilai-nilai. Tentang siswa Anda. Nilai-nilai Islam humanistik bahkan Islam radikal diajarkan. Oleh karena itu, selektivitas juga penting untuk menentukan wajah pesantrain. Pada akhirnya, para siswa diwarnai oleh wali mereka.

${ }^{38}$ Nurison, Peran Pondok Pesantren Dalam Pembangunan Budaya Damai, 59. 
i. Model pendidikan untuk mencegah pemikiran-pemikiran radikal, pendidik harus mencerminkan implementasi ajaran perdamaian Islam. Karena inkonsistensi pendidik akan berdampak negatif pada peserta didiknya dalam hal prinsip hidup.

j. Kelahiran kembali adalah bagian terpenting untuk menumbuhkan karakter santri melalui pelatihan maupun kursus-kursus yang dilakukan.

\section{Strategi Mengintegrasikan Nilai-Nilai}

Masalah orang menjadi semakin rumit, sehingga banyak orang melakukan kesalahan dalam mengambil keputusan hidup. Situasi ini membuat santri semakin bingung, dan mereka dipaksa untuk membuat pilihan atau keputusan. Idealnya, pilihan akan didasarkan pada nilai yang Anda pegang. Namun terkadang mereka tidak sepenuhnya jelas tentang nilai-nilai mereka.

Pesantren adalah lembaga pendidikan yang menanamkan nilai dan ilmu pengetahuan (value and knowledge transfer) yang mempunyai fungsi sosial dan dapat memberikan kontribusi bagi terwujudnya kehidupan masyarakat yang tentram dan harmonis. Di lembaga pendidikan maupun di masyarakat dan negara, nilai-nilai yang akan membimbing hidup Anda, seperti kebebasan, kesetaraan, toleransi, persatuan, keadilan, kejujuran dan kesabaran. Frenkel percaya bahwa integrasi nilai dapat dicapai melalui integrasi budaya secara materil. Memberikan metode atau cara mengajar kemudian dievaluasi secara bersama, integrasi budaya semacam itu berarti pembentukan perilaku dengan diwujudkan sebagai pengalaman belajar, dan siswa mengharapkan diversifikasi nilai 39 .

Di bidang pendidikan, tujuan mereka ada tiga hal. Pertama, membantu siswa memahami pentingnya nilai dalam kehidupan manusia. Kedua, membantu siswa mengembangkan nilai-nilai pendidikan. Ketiga, membantu siswa memahami apa artinya bersikap baik kepada teman sekelas. proses integrasi pesantren. Kursus mengantisipasi etika, perilaku, kebajikan, dan internalisasi sebagai nilai-nilai praktis dan layak huni bagi santri. Belajar tekun dipesantren akan mendapatkan hasil akhir yang baik. Ketika siswa mempelajari berbagai ilmu, membaca menjadi alat; pada tahap ini, bidang pengetahuan berakhir. Beginilah proses integrasi terjadi dalam pendidikan: dalam penerjemahan, pemahaman diwujudkan, kemudian diasimilasi dalam mencapai proses dalam mentransformasikan.

${ }^{39}$ Subchi Imam, Muzaik Pemikiran Islam (Jakarta: Dirjen Diktis Kemenag, RI, 2011), 6 .

376 JURNAL LISAN AL-HAL 


\section{Simpulan}

Nilai dan etika dalam ta'lim nuta'allim mewakili delapan nilai bertujuan untuk mencegah radikalisme menyerang pesantren, antara lain: kehati-hatian, kesabaran, ketekunan, taat, hormat dan martabat yang luhur. Hargai dirimu dan lakukan yang terbaik. Oleh karena itu, aktivisme merupakan musuk kita semua. Kita pada dasarnya berbeda, kita harus bisa bekerja sama. Hubungan baik dengan agama lain. Mereka juga bisa dijadikan benteng jika ingin melawan agama-agama yang berbeda, nilainilai aliansi telah terbentuk, dan sulit untuk menciptakan perselisihan dan menghindari konflik. Oleh karena itu, nilai toleransi adalah yang terpenting. Mirip dengan jembatan antar umat beragama.

Terungkap pesantren yang diduga pabrik teroris karena keyakinan radikalisme dan pesantren sangat berbeda, tidak semua rumor dan rumor itu benar. Karena itu, terorisme biasanya didasarkan pada pengetahuan dan pemahaman Anda tentang agama. Kuat, tapi akhlaknya buta dan sombong. Pondok Pesantren Untuk memprediksi dan memerangi radikalisme dan terorisme di pondok pesantren, pondok pesantren menggunakan berbagai metode. anak-anak. Dan hanya ada fiqh, dan itu juga terkait dengan pemikiran filosofis dan tasawuf. Pesantren juga harus mengadopsi teologi yang lebih inklusif, ramah, dan toleran. Budaya demokrasi yang didukung kuat oleh pesantren perlu dipertahankan dan dikembangkan untuk mendukung argumentasi teologis yang dapat digunakan. Langkah-langkah yang akan dikembangkan sebagai pendukung. Pertama, mengajarkan santri untuk memahami pentingnya nilai-nilai dalam kehidupan seseorang. Kedua, mendorong siswa untuk selalu mengembangkan dan memperdalam nilai-nilainya. Ketiga, mereka mendorong siswa untuk menjadi panutan yang baik dan bertanggung jawab.

\section{DAFTAR PUSTAKA}

Agus, SB. Darurat Terorisme Kebijakan Pencegahan, Perlndungan Dan Deradikalisasi. Jakarta: Daulat Press, 2014.

Ahmad, Nuhu, Nahidi. Buro Fur Islamische Internate Und Sozialen Wandel. Jakarta: Pusat Pengembagan, Penelitian dan Keagamaan, Kementerian Agama, Republik Indonesia, n.d.

Asshofie, Agil. "Radikalisme Gerakan Islam." Agilasshofie.Blogspot.Com, 2011.

Departemen, Agama, RI. Al-Qur'an Dan Terjemahnya. Jakarta: CV. Jamanatul Ali-ART, 2004. 
Dhofier, Zamakhsyari. “Tradisi Pesantren, Cet.” VI, Jakarta: LP3ES (1994).

Esposito, John L, and Syafruddin Hasani. "Unholy War: Teror Atas Nama Islam. Terj." Syafrudin Hasani, Yogyakarta: Ikon Teralitera (2003). Harun, Nasution. Islam Rasional: Gagasan Dan Pemikiran Prof. Dr. Harun Nasution. Bandung: Mizan, 1996.

Imam, Subchi. Muzaik Pemikiran Islam. Jakarta: Dirjen Diktis Kemenag, RI, 2011.

Karagiannis, Emmanuel. "Political Islam in Uzbekistan: Hizb Ut-Tahrir alIslami." Europe-Asia Studies 58, no. 2 (2006): 261-280.

Lexy, Meleong, J. Metodologi Penelitian Kualikatif. Bandung: Remaja Rosada Karya, 2010.

Madjid, Nurcholis. Bilik-Bilik Pesantren: Sebuah Potret Perjalanan. Paramadina, 1997.

Moh, Yamin. Menggugat Pendidikan Indonesia. Yogyakarta: Ar-Ruz Media, Cet. 1, 2009.

Muhaimin. Pendidikan Islam: Mengurangi Benang Kusut Dunia Pendidikan. Jakarta: PT. Raja Grafindo Persada, 2006.

Muslim. “No Title," 3977.

Nasir, M Ridlwan. Mencari Tipologi Format Pendidikan Ideal: Pondok Pesantren Di Tengah Arus Perubahan. Pustaka pelajar, 2005.

Nurison, M Nuh. Peran Pondok Pesantren Dalam Pembangunan Budaya Damai. Jakarta: Kementerian Riset dan Pengembangan Agama dan Biro Pendidikan, 2010.

Nursyamsu Mt, Mohammad Faqih. "Dinamika Sistem Pendidikan Di Pondok Pesantren Dalam Mengahadapi Era Globalisasi: Studi Multikasus Pondok Pesantren Darul Huda Mayak Ponorogo Dan Pondok Pesantren Thoriqul Huda Cekok Ponorogo." Universitas Islam Negeri Maulana Malik Ibrahim, 2016.

Qodir, Zuly. Radikalisme Agama Di Indonesia. Yogyakarta: Pustaka Pelajar, 2014.

Rakhmawati, Rakhmawati. "POLA PENGASUHAN SANTRI DI PONDOK PESANTREN DALAM MENGANTISIPASI RADIKALISME: Studi Pada Pesantren Ummul Mukminin Dam Pondok Madinah." Jurnal Diskursus Islam 1, no. 1 (n.d.): 36-55.

Sirry, Mun'in, A. Membendung Militansi Agama: Iman Dan Politik Dalam Masyarakat Modern. Jakarta: Erlangga, 2003.

Steve, Bruce. Fundamentalisme: Pertautan Keberagaman Dan Modernitas. Jakarta: Erlangga, 2000.

Sugiono. Metode Penelitian Kualitatif, Kuantitatif. Bandung: Alfabeta, 2009.

$378 \mid$ JURNAL LISAN AL-HAL 
Suryahardi, Irfan Awwas. Dakwah \& Jihad Abu Bakar Ba'asyir. Yogyakarta: Wahdah Press, 2003.

Tempo. "Jokowi Usul Ganti Istilah Radikalisme Jadi Manipulator-Agamal." Nasional.Tempo.Co, 2019.

Wahid, Abdurrahman. Ilusi Negara Islam: Ekspansi Gerakan Islam Transnasional Di Indonesia. Jakarta: The Wahid Institute, 2009.

Wildan, Muhammad. "Mewaspadai Bahaya Ekstremisme Dan Radikalisme Di Kampus." Lecturer at UIN Sunan Kalijaga Yogyakarta, 2018.

Wiryosukarto, Amir Hamzah, and Ahmad Fuad Efendi. "KH Imam Zarkasyi Dari Gontor Merintis Pesantren Modern.” Ponorogo: Gontor Press, 1996.

Zarnuji, AZ. Ta'lim Muta'allim Thariq At-Ta'allum. Bairut Lebanon: Dar AlKottob Al-ilmiyah, 2012. 
"Nilai-Nilai Ta'limul Muta'allim Mencegah Radikalisme"

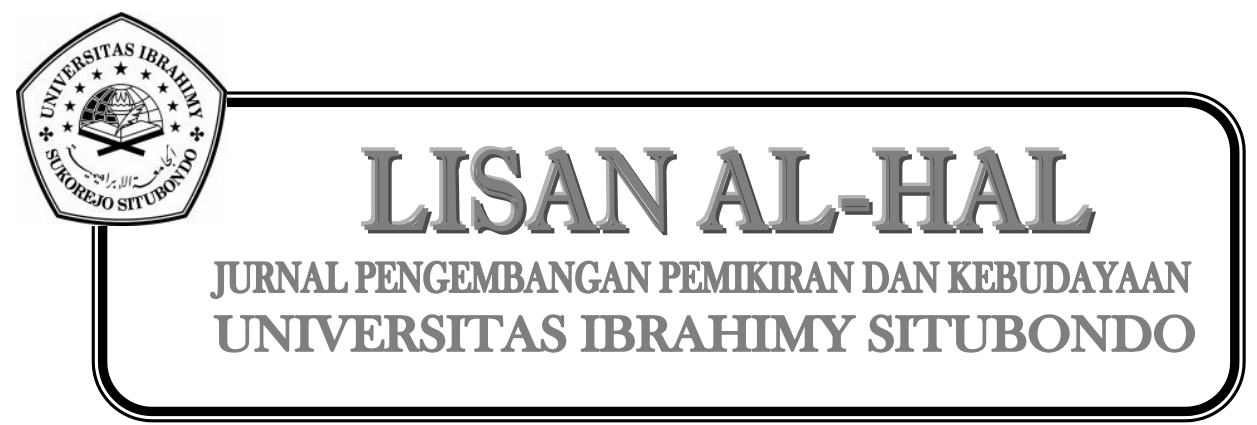

380 JURNAL LISAN AL-HAL 